九州大学学術情報リポジトリ

Kyushu University Institutional Repository

\title{
A Study on the Cultivation and Production of Korean Paper Mulberries and Korean Paper Manufactures
}

Kang, Hag Mo

Gyeongi-do Forest Environment Research Station

Koroki, Katsuhisa

Department of Forest and Forest Products Sciences, Fuculty of Agriculture, Kyushu Unviversity

https://doi.org/10.5109/10105

出版情報: 九州大学大学院農学研究院紀要. 53 (1)，pp.291-297，2008-02-28. Faculty of Agriculture, Kyushu University

バージョン :

権利関係 : 


\title{
A Study on the Cultivation and Production of Korean Paper Mulberries and Korean Paper Manufacturers
}

\section{Hag Mo KANG ${ }^{*}$ and Katsuhisa KOHROKI}

Laboratory of Forest Policy, Division of Forest Environment and Management Sciences, Department of Forest and Forest Products Sciences, Faculty of Agriculture, Kyushu University, Fukuoka 812-8581, Japan

(Received October 31, 2007 and accepted November 30, 2007)

\begin{abstract}
Korean paper made from paper mulberry (Broussonetia Kazinoki Siebold) fibers is tough, very strong, and pliable, and, being acid-free, it lasts longer than the acidic Western paper. It has, therefore, been used widely for storing important documents and records. It also has excellent characteristics, such as ventilation, a soft touch, water absorption, and soundproofness compared with the Western paper, and it has been used in a number of fields, including living necessities and craft material. However, most Korean paper manufacturers are closed, because it is becoming difficult to run successful businesses all year round as business is being influenced by the decreases and aging of the labor force in farming villages, the increase of labor costs in Korea, the increase of imports of cheap raw materials from China and Southeast Asia, and the decrease of demand. The number of Korean paper producing farmhouses is also decreasing rapidly, meaning the production basis for paper mulberry in Korea is in decline. However, there have been almost no studies on farmhouses producing paper mulberries or Korean paper manufacturers. This study, therefore, was intended to determine a way to activate the Korean paper manufacturing industry and the paper mulberry production among farmhouses, by examining the cultivation status of paper mulberry producing farmhouses, and the operating status of Korean paper manufacturers. As a result, the cultivation of paper mulberries was found to need to move away from small-scale production using small fields and remaining land, toward large-scale production using forests and fields. It was also found that the production of Korean paper needs the support and management of the government so that manufacturers can establish a clear concept of what Korean paper is, and differentiate its characteristics in order to keep traditional Korean paper alive.
\end{abstract}

\section{INTRODUCTION}

The paper mulberries used as the raw material for Korean paper are the paper mulberry, the paper bush (Edzeworthia papyrifera Siebold), wild mulberry, and so on. However, only two types, the paper mulberry and the paper bush, are officially produced in Korea. Korean paper, made with paper mulberry fiber, is tough, strong, and pliable. Notably, it is acid-free and lasts longer than the acidic Western paper, and has been widely used for storing important documents and records. It also has excellent characteristics, such as ventilation, a soft touch, water absorption, and soundproofness compared with Western paper. It has been used in a number of fields, including living necessities and craft material. Korean paper has been produced for over 600 years, although many Korean paper manufacturers have now closed their businesses, as it has become difficult to operate the business all year round, and the scale of paper mulberry fiber production in Korea is gradually decreasing, with the decreases and aging of the labor force in farming villages, the increase of labor costs in Korea, the increase of imports of cheap raw materials from China and Southeast Asia, and the decrease of demand. Furthermore, the Korean paper manufacturing industry is losing its foothold (Korea Forest Service,

\footnotetext{
1 Gyeonggi-do Forest Environment Research Station, Osan, Gyeonggi-do Forest Environment Research Station, Osan, 447-290, Korea

* Corresponding author (E-mail: kanghagmo@hanmail.net)
}

2001). Even under these difficult situations, the municipality of Jeonju has developed a large-scale paper mulberry forest, extending $660,000 \mathrm{~m}^{2}$, in order to reexamine the excellence of Korean paper and foster it into a high value-yielding industry, by developing various uses. There have, as yet, been very few studies about paper mulberry producing farmhouses and Korean paper manufacturers. Therefore, this study aims to determine the current issues facing the industry, and examine directions of development in the future, through an empirical investigation of paper mulberry cultivators and producers, as well as Korean paper manufacturers, in order to help reactivate the gradually declining Korean paper industry.

\section{METHODS OF STUDY}

For sampling, 11 paper mulberry cultivators and producers, (eight people in Suncheon, Jeollanam-do, two people in Goheung, Jeollanam-do, and one person in Goesan-gun, Chungcheongbuk-do), and 14 Korean paper manufacturers, (three companies in Jeonju, Jeollabuk-do, one company in Imsil-gun, Jeollabuk-do, three companies in Euiryeong-gun, Gyeongsangnam-do, one company in Andong, Gyeongsangbuk-do, one company in Mungyeong, Gyeongsangbuk-do, two companies in Wonju, Gangwon-do, one company in Gapyeong-gun, Gyeonggi-do, one company in Pyeongtaek, Gyeonggi-do, and one company in Goesan-gun, Chungcheongbuk-do), were surveyed. The survey was performed through direct surveys over two months from the beginning of 
July to the end of August 2007, and the content of the survey was constituted with the cultivation experience, cultivation status, sales and distribution, and future plans for paper mulberry cultivators and producers, as well as the Korean paper manufacturing experience, scale of factory production, methods of supply of raw materials, types of products, production scale, and sales and distribution for Korean paper manufacturers.

\section{RESULTS AND DISCUSSION}

\section{Production and Export of Paper Mulberry Fiber in Korea}

Paper Mulberry Cultivating and Producing Farmhouses and Korean Paper Manufacturers

There were 78 farm households cultivating paper mulberry and 168 farm households manufacturing paper bush, in 2001 (Korea Forest Service, 2001). However, at the end of 2003, 128 farm households were producing paper mulberry and paper bush. $77 \%$ of producers were in their 60s or older, and mulberry cultivators and producers of Gapyeong-gun had 27 years of experience on average. The annual average household income was 21 million won. However, only 500,000 won was earned from cultivating the paper mulberries. Although they answered that they sold most of the yield to merchants (Kim, 2005), it was difficult to locate official data from farm households producing paper mulberry by 2007.

On the other hand, there were 64 Korean paper manufacturers in 1996 and 52 in 2001 ${ }^{2}$. However, the internal data collected by the government research agency showed that there were only 20 as of 2007 (Korea Forest Research Institute, 2007). The actual survey based on the said data showed that even some of those 20 companies have already closed their businesses or suspended production for health reasons.

Annual Production and Export of Paper Mulberry Fiber

a) Annual Paper Mulberry Fiber Production Status

The production of paper mulberries include two species: paper mulberry and paper bush. However, paper bush constitutes most of the production. The yields and production levels in 1997 were $450,000 \mathrm{~kg}$ and 4 billion won, however they were reduced enormously to $26,000 \mathrm{~kg}$ and approximately 70 million won by 2003 . These levels did increase, however, by four times and 2.5

Table 1. Annual Paper Mulberries Fiber Production Status

\begin{tabular}{|c|c|c|c|c|c|c|c|}
\hline & \multirow[b]{2}{*}{ Division } & \multicolumn{2}{|c|}{ Total } & \multicolumn{2}{|c|}{ Paper Mulberry } & \multicolumn{2}{|c|}{$\begin{array}{c}\text { Paper Bush } \\
\text { (Edzeworthia Papyrifera) }\end{array}$} \\
\hline & & $\begin{array}{l}\text { Production } \\
\quad(\mathrm{kg})\end{array}$ & $\begin{array}{c}\text { Amount } \\
\text { (1 Million } \\
\text { Won) }\end{array}$ & $\begin{array}{l}\text { Production } \\
\text { (kg) }\end{array}$ & $\begin{array}{c}\text { Amount } \\
\text { (1 Million } \\
\text { Won) }\end{array}$ & $\begin{array}{l}\text { Production } \\
\quad(\mathrm{kg})\end{array}$ & $\begin{array}{c}\text { Amount } \\
\text { (1 Million } \\
\text { Won) }\end{array}$ \\
\hline \multirow{5}{*}{ Year } & 1997 & 448,188 & 4,050 & 61,338 & 181 & 386,850 & 3,869 \\
\hline & 1998 & 266,765 & 1,488 & 32,081 & 133 & 234,684 & 1,355 \\
\hline & 2000 & 263,487 & 3,733 & 18,585 & 59 & 244,902 & 3,674 \\
\hline & 2003 & 25,773 & 66 & 13,050 & 46 & 12,723 & 20 \\
\hline & 2005 & 99,525 & 170 & 21,375 & 126 & 78,150 & 44 \\
\hline \multirow{3}{*}{ Region } & Jeollanam-do & $\begin{array}{r}80,346 \\
(81)\end{array}$ & 53 & 2,196 & 9 & 78,150 & 44 \\
\hline & Gyeongsangbuk-do & $\begin{array}{r}10,679 \\
(11)\end{array}$ & 63 & 10,679 & 63 & & \\
\hline & Gyeongsangnam-do & $\begin{array}{r}8,500 \\
(8)\end{array}$ & 54 & 8,500 & 54 & & \\
\hline
\end{tabular}

Note: Value inside ( ) indicates the distribution ratio (\%).

Source: Korea Forest Service. 2006 Forestry Statistics.

Table 2. Annual Mulberry Bark Export and Import Status

\begin{tabular}{|c|c|c|c|c|c|}
\hline \multirow{2}{*}{\multicolumn{2}{|c|}{ Division }} & \multicolumn{2}{|c|}{ Export } & \multicolumn{2}{|c|}{ Import } \\
\hline & & \multirow{2}{*}{$\begin{array}{c}\begin{array}{c}\text { Quantity } \\
\text { (kg) }\end{array} \\
6,000\end{array}$} & \multirow{2}{*}{$\begin{array}{c}\begin{array}{c}\text { Amount } \\
(1,000 \text { USD })\end{array} \\
18\end{array}$} & \multirow{2}{*}{$\begin{array}{l}\text { Quantity } \\
\text { (kg) }\end{array}$} & \multirow{2}{*}{$\begin{array}{c}\text { Amount } \\
(1,000 \text { USD })\end{array}$} \\
\hline \multirow{8}{*}{ Year } & 1982 & & & & \\
\hline & 1985 & 57,000 & 311 & & \\
\hline & 1990 & 146,000 & 1,167 & & \\
\hline & 1995 & 75,000 & 901 & & \\
\hline & 2000 & 62,000 & 655 & 136,000 & 127 \\
\hline & 2003 & 36,000 & 285 & 88,00 & 82 \\
\hline & 2005 & 29,000 & 344 & 143,000 & 147 \\
\hline & 2006 & & & 67,000 & 73 \\
\hline
\end{tabular}

Note: The income data was from the Korea Agro-Fisheries Trade Corporation.

Source: 1) Korea Forest Service, Forestry Statistics 2006

2) Korea Agro-Fisheries Trade Corporation homepage, Export and Import Statistics by Year, Forest Product · Tree Barks · Paper Mulberry Bark. 
times respectively in 2005, compared to 2003. Paper mulberry and paper bush were produced in three provinces in 2005. However, Jeollanam-do produces $81 \%$ of the entire yield and Gyeongsangbuk-do and Gyeongsangnam-do, 11\% and 8\%, respectively (Korea Forest Service, 2006) (Table 1).

b) Annual Import and Export of Paper Mulberry Bark

The annual import and export of paper mulberry bark shows that imports have gradually decreased from the peak production of approximately $150,000 \mathrm{~kg}$ in 1990 to approximately $30,000 \mathrm{~kg}$ in 2005 . However, the paper mulberry fiber produced in Korea is of an excellent quality, and paper bush cultivated in the Southern coastal areas is not consumed domestically, but is entirely exported to Japan. On the other hand, imports have represented two to five times the export level since 2000, and imports increased up to 140,000 kg by 2005 . Imports primarily come from China and Thailand (Korea Forest Service, 2006; Korea Forest Service, 2001; Korea Agro-Fisheries Trade Corporation, 2007) (Table 2).

\section{Case Study}

Paper Mulberry Cultivating and Producing Farmhouses

a) General Status of Paper Mulberry Cultivating and Producing Farmhouses

The average age of the 11 respondents was 64, and two people were in their 40s. Two others were in their 50s. Four people were in their 60s, and three people were in their 70s. One respondent in Goesan-gun, Chungcheongbuk-do cultivates paper mulberry while operating a Korean paper manufacturing company, and two people in Goheung-gun, Jeollanam-do cultivate paper mulberry while collecting paper mulberry bark from neighboring areas, including Suncheon, processing them into white skin for sale. All eight people in Suncheon, Jeollanam-do, were selling paper mulberries to a merchant in Goheung-gun without processing them. Concerning the cultivation experience, one respondent in Goesan-gun had 13 years of experience, two respondents in Goheung-gun had five and 27 years, respectively, of experience, and most respondents in Suncheon had 30 years of experience. Nine respondents cultivated paper mulberry, and two respondents cultivated paper bush. Concerning the cultivation scale, three people had $330 \mathrm{~m}^{2}$ of land, one person had $495 \mathrm{~m}^{2}$ of land, two people had $660 \mathrm{~m}^{2}$ of land, one person had $990 \mathrm{~m}^{2}$ of land, one person had $1,320 \mathrm{~m}^{2}$ of land, one person had $1,650 \mathrm{~m}^{2}$ of land, one person had $1,980 \mathrm{~m}^{2}$ of land, and one person had $13,200 \mathrm{~m}^{2}$ of land. The average cultivation scale of the ten people, excluding that with $13,200 \mathrm{~m}^{2}$ of land, was $875 \mathrm{~m}^{2}$, which decreased by $60 \%$ from $1,469 \mathrm{~m}^{2}$. Some cultivators tried to maintain the number of trees through supplementation, while most cultivators responded that the number of trees decreased due to withering and negligence. Concerning the motivation for cultivation, the respondent in Goesangun cultivated trees to produce Korean paper singularly, with the motivation for the respondents in other areas being to increase family income through exports (Table 3).

b) Paper Mulberry Fiber Production

One cultivator in Goesan-gun produced $420 \mathrm{~kg}$ of mulberry bark and $180 \mathrm{~kg}$ of bleached mulberry bark for self-consumption. Two people in Goheung-gun produced $800 \mathrm{~kg}$ of mulberry bark and collected $3,700 \mathrm{~kg}$, but processed them into bleached mulberry bark and sold them. The price was around 9,000-10,000 won for $1 \mathrm{~kg}$, despite being approximately 14,000-15,000 won five years ago. In Suncheon, unprocessed mulberries were sold for between 320-550 won for $1 \mathrm{~kg}$, with these prices being 500-700 won five years ago. In Goheunggun, mulberry bark was processed during the off-season, and bleached bark was sold around May. In Suncheon, the products were sold to a visiting merchant around March. The average gross income of the ten households in 2006, excluding the 200 million won of the one respondent who runs a Korean paper manufacturing company, was 16.49 million won. However, there were five cultivators whose gross income was less than ten million won. Excluding Goesan-gun, the percentage of paper mulberry production in the total gross household income of ten people was $27 \%$, but for eight people in Suncheon, the gross income earned from paper mulberry production was only 330,000 won, and it represented only a $3 \%$ share of the domestic economy (Table 4 ).

For reference, the gross income earned from mulberry production in Suncheon was measured in 2005,

Table 3. Cultivation Experience and Scale

\begin{tabular}{clrrrr}
\hline \multirow{2}{*}{ Division } & Cultivation Location & Age & $\begin{array}{c}\text { Cultivation } \\
\text { Experience } \\
\text { (Year })\end{array}$ & $\begin{array}{c}\text { Cultivation } \\
\text { Scale } \\
\left(\mathrm{m}^{2}\right)\end{array}$ & Paper Mulberries \\
\hline 1 & Goesan-gun, Chungcheongbuk-do & 49 & 13 & 13,200 & Paper Mulberry \\
2 & Goheung-gun, Jeollanam-do & 67 & 5 & 990 & Paper Bush \\
3 & Goheung-gun, Jeollanam-do & 75 & 27 & 330 & Paper Bush \\
4 & Suncheon, Jeollanam-do & 76 & 30 & 330 & Paper Bush \\
5 & Suncheon, Jeollanam-do & 57 & 8 & 1,650 & Paper Mulberry \\
6 & Suncheon, Jeollanam-do & 58 & 10 & 1,980 & Paper Bush \\
7 & Suncheon, Jeollanam-do & 47 & 30 & 495 & Paper Bush \\
8 & Suncheon, Jeollanam-do & 68 & 30 & 660 & Paper Bush \\
9 & Suncheon, Jeollanam-do & 75 & 30 & 330 & Paper Bush \\
10 & Suncheon, Jeollanam-do & 67 & 30 & 660 & Paper Bush \\
11 & Suncheon, Jeollanam-do & 65 & 28 & 1,320 & Paper Bush \\
\hline
\end{tabular}


Table 4. Mulberry Fiber Production and Sales Volume

\begin{tabular}{|c|c|c|c|c|c|c|c|}
\hline \multirow{3}{*}{ Division } & \multirow{3}{*}{ Location of Cultivators } & \multirow{3}{*}{ Age } & \multicolumn{3}{|c|}{ Production (kg) } & \multirow{3}{*}{$\begin{array}{l}\text { Production } \\
\text { (10,000 } \\
\text { Won) }\end{array}$} & \multirow{3}{*}{$\begin{array}{l}\text { Gross Income o } \\
\text { All Households } \\
\text { (10,000 Won) }\end{array}$} \\
\hline & & & \multicolumn{2}{|c|}{ Self-Produced } & \multirow{2}{*}{$\begin{array}{c}\text { Collection } \\
\text { Mulberry } \\
\text { Bark }\end{array}$} & & \\
\hline & & & $\begin{array}{c}\text { Mulberry } \\
\text { Bar }\end{array}$ & $\begin{array}{c}\text { Bleached } \\
\text { Bark }\end{array}$ & & & \\
\hline 1 & Goesan-gun, Chungcheongbuk-do & 49 & 420 & 180 & & Self-Consumed & 20,000 \\
\hline 2 & Goheung-gun, Jeollanam-do & 67 & 600 & & 1,400 & 2,000 & 3,050 \\
\hline 3 & Goheung-gun, Jeollanam-do & 75 & 200 & & 1,300 & 2,250 & 3,750 \\
\hline 4 & Suncheon, Jeollanam-do & 76 & 375 & & & 15 & 715 \\
\hline 5 & Suncheon, Jeollanam-do & 57 & 500 & & & 28 & 2,028 \\
\hline 6 & Suncheon, Jeollanam-do & 58 & 1,200 & & & 60 & 600 \\
\hline 7 & Suncheon, Jeollanam-do & 47 & 1,000 & & & 40 & 3,040 \\
\hline 8 & Suncheon, Jeollanam-do & 68 & 600 & & & 23 & 503 \\
\hline 9 & Suncheon, Jeollanam-do & 75 & 940 & & & 30 & 430 \\
\hline 10 & Suncheon, Jeollanam-do & 67 & 750 & & & 30 & 830 \\
\hline 11 & Suncheon, Jeollanam-do & 65 & 800 & & & 40 & 1,540 \\
\hline
\end{tabular}

and purchases have not been made since 2006, as the merchant offered too low a price. Concerning the cost used for the production of paper mulberry fiber, Goesangun's gross income was 150 million won. However, it cost a total of 3.46 million won, including two million won for labor costs for irrigation and weeding, 500,000 won for food, and 960,000 won for fertilizers. The gross income that two people in Goheung-gun earned from mulberry were 20 million won and 22.5 million won, respectively, although they spent 15.75 million won and 7.8 million won in costs, and $90 \%$ of this was used to service labor costs for the bleaching process. In Suncheon, cultivators only spent about 10,000 won on fertilizers.

c) Management of Paper Mulberry and Future Plans

Lumbering took place once a year in the entire area, however it did not take place in Suncheon as mulberry fiber has not been traded since 2006. Cultivators in Goesan-gun and Goheung-gun answered that they did not increase the number of trees, but only went as far as replacing withered trees. Pertaining to the difficulties in cultivation, cultivators chose weeding and high withering rates, although they responded that the most difficult thing about growing paper mulberry is that it is sold at such a low price, and yet, remains difficult to sell. Regarding the future plans for mulberry cultivation, one respondent in Goesan-gun wanted to expand the scale of forestation from the current $13,200 \mathrm{~m}^{2}$ up to 660,000 $990,000 \mathrm{~m}^{2}$ for the production of Korean paper, and two people in Goheung-gun were planning to reduce their production scales due to high withering rates of trees and the difficult bleaching process. All eight people in Suncheon answered that they would turn to other crops, such as beans, garlic, apricots, and chestnuts by 2008 if they cannot find a way to trade mulberries.

Korean Paper Manufacturers

a) General Status of Korean Paper Manufacturers

The 14 Korean paper manufacturers that responded to the survey are located in four cities and counties in Jeollabuk-do, three counties in Gyeongsangnam-do, two cities in Gyeongsangbuk-do, two cities and counties in Gangwon-do, and one county in Chungcheongbuk-do. The size of the space available for production was 99-1,584 $\mathrm{m}^{2}$, and the average was $505 \mathrm{~m}^{2}$. However, ten companies had production spaces smaller than the average sizes. As many companies have been operating the mulberry business for generations, with the average experience of companies being 42 years. The average

Table 5. Korean Paper Production Space and Experience in Production

\begin{tabular}{|c|c|c|c|c|c|}
\hline Division & Company Location & $\begin{array}{c}\text { Production } \\
\text { Space } \\
\left(\mathrm{m}^{2}\right)\end{array}$ & $\begin{array}{c}\text { Experience } \\
\text { in Production } \\
\text { (Year) }\end{array}$ & $\begin{array}{l}\text { Capital } \\
\text { (10 Million } \\
\text { Won) }\end{array}$ & $\begin{array}{c}\text { Employees } \\
\text { (Persons) }\end{array}$ \\
\hline 1 & Euiryeong-gun, Gyeongsangnam-do & 99 & 100 & & 3 \\
\hline 2 & Jeonju, Jeollabuk-do & 139 & 9 & 8 & 2 \\
\hline 3 & Jeonju, Jeollabuk-do & 142 & 47 & & 5 \\
\hline 4 & Wonju, Gangwon-do & 149 & 54 & 3 & 3 \\
\hline 5 & Gapyeong-gun, Gyeonggi-do & 198 & 56 & 30 & 5 \\
\hline 6 & Wonju, Gangwon-do & 231 & 50 & 8 & 5 \\
\hline 8 & Euiryeong-gun, Gyeongsangnam-do & 264 & 40 & 20 & 3 \\
\hline 7 & Jeonju, Jeollabuk-do & 264 & 22 & & 8 \\
\hline 10 & Mungyeong, Gyeongsangbuk-do & 330 & 56 & & 3 \\
\hline 9 & Imsil-gun, Jeollabuk-do & 330 & 50 & & 2 \\
\hline 11 & Goesan-gun, Chungcheongbuk-do & 528 & 26 & 4 & 5 \\
\hline 12 & Euiryeong-gun, Gyeongsangbuk-do & 1,320 & 29 & 80 & 5 \\
\hline 13 & Pyeongtaek, Gyeonggi-do & 1,485 & 18 & & 4 \\
\hline 14 & Andong, Gyeongsangbuk-do & 1,584 & 37 & 50 & 30 \\
\hline
\end{tabular}


capital amounts of the eight companies that revealed the size of their capital was 250 million won, and the average number of employees was six (Table 5).

b) The Production of Korean Paper

There are two ways to produce Korean paper: manual and mechanical methods. The manual method is divided into the single screen method and the double screen method. The single screen method is used for increasing the strength of the paper by applying dakpul (Hibiscus manihot Linne) on the front, back, left, and right sides of the screen frame, so as to even out the pulp so that the fiber tissues bond with each other in all directions. The double screen method makes one sheet of paper at a time, by placing two screens, one on top of the other, so that they cross each other and lock the water in, so as to sink the fiber tissues such that it becomes convenient to make paper. The strength of the paper does decrease using this method, as the tissues are placed in the same direction and are not bonded well with each other. Therefore, the single screen method is mainly used by companies that stick to traditional Korean paper, or by those companies that mainly use the double screen method, but that also need to produce high quality paper for art work and preserving books. The double screen method is mainly used for producing inexpensive Korean paper. Among 14 companies, six used both single and double screen methods, three companies used the double screen method, and two companies used the single screen method. Two companies used the mechanical method, and one company used a semi-mechanical method. All the three companies with relatively large production spaces used the mechanical method. Ten companies among the 14 companies operated all year round, and the average production of 11 companies with the same production units was 190,000 sheets. However, comparing to production levels in the past, five - ten years ago, four companies stated that their production levels reduced by $50 \%$ or more due to the import of cheap paper from China, and the decreased demand for Korean paper. The average production of the three companies with relatively large production spaces was 700 million won, while that of the 11 additional companies was less than 130 million won (Table 6).

c) Raw Materials and Products

Concerning the supply of raw materials, five companies used Korean paper mulberry and imported pulp, four companies used Korean paper mulberry, four companies used Korean paper mulberry and imported paper mulberry, and one company used Korean paper mulberry, imported paper mulberry, and also imported pulp. For Korean paper mulberry, most companies purchased it from merchants instead of cultivating it by themselves, and imported paper mulberries and pulp came largely from Thailand, China, and Canada. On the other hand, these companies produced a great variety of paper products, including wallpaper, floor paper, natural dye paper, mud paper, paper with embossed patterns, and paper with water drop patterns of various sizes, thicknesses, and materials, rather than simply produce traditional Korean paper and drawing paper. One of these companies produced over 200 different types of paper. The reason the quantity decreased, but the variety increased, compared to the past, appears to be that the demand for traditional Korean paper decreased, with producers needing to respond by developing various different paper products. Paper was mostly manufactured on order, delivered to clients, or sold through door-to-door sales methods. However, two companies had stores and exhibition halls under their direct management. Two companies answered that their clients included artists, temples, government organizations and museums, with one company answering that they exported 30\% of their production to Japan. The remaining companies primarily dealt with wallpaper companies and paper shops, and two companies answered that their stock was increasing as orders fell.

d) Difficulties in Production and Future Plans

Regarding the difficulties facing the Korean paper industry, there were many opinions, including a lack of technicians and initiates, difficulties in purchasing domestic raw materials, the increase in labor costs, the

Table 6. Korean Paper Production

\begin{tabular}{|c|c|c|c|c|c|}
\hline Division & $\begin{array}{l}\text { Production } \\
\text { Space } \\
\left(\mathrm{m}^{2}\right)\end{array}$ & Production Method & $\begin{array}{l}\text { Production } \\
\text { Period }\end{array}$ & $\begin{array}{c}\text { Production } \\
(10,000 \\
\text { Sheets })\end{array}$ & $\begin{array}{l}\text { Production } \\
\text { (10 Million } \\
\text { Won) }\end{array}$ \\
\hline 1 & 99 & Single Screen Method & 2 Months & 2 & 2 \\
\hline 2 & 139 & Double Screen Method & All Year Round & 15 & 4 \\
\hline 3 & 142 & Single Screen Method · Double Screen Method & All Year Round & 18 & 9 \\
\hline 4 & 149 & Single Screen Method · Double Screen Method & All Year Round & 34 & 13 \\
\hline 5 & 198 & Single Screen Method · Double Screen Method & All Year Round & 29 & 30 \\
\hline 6 & 231 & Double Screen Method & All Year Round & 30 & 30 \\
\hline 7 & 264 & Single Screen Method · Double Screen Method & All Year Round & 54 & 30 \\
\hline 8 & 264 & Single Screen Method · Double Screen Method & 8 Months & 2 & 7 \\
\hline 9 & 330 & Semi-Mechanical & 6 Months & 2 & 3 \\
\hline 10 & 330 & Single Screen Method & All Year Round & 0.8 & 3 \\
\hline 11 & 528 & Single Screen $\cdot$ Double Screen Method & All Year Round & 20 & 15 \\
\hline 12 & 1,320 & Mechanical & All Year Round & 500 ton & 100 \\
\hline 13 & 1,485 & Mechanical & All Year Round & 12 ton & 40 \\
\hline 14 & 1,584 & Double Screen Method & 10 Months & & 70 \\
\hline
\end{tabular}


decrease of demand for Korean paper, weak price competitiveness due to the increase of imported raw materials and products, the increase of stock, the increase of material costs, and difficulties in finding markets. Regarding the support from central and local governments, four companies answered that they received government support, such as the lease of land for the construction of an exhibition hall, funds for the activation of Korean paper manufacturer associations due to the collectivization of Korea paper manufacturers, the lease of land, and funds for the construction of new manufacturing facilities. Nevertheless, some producers also suggested that the collectivization of Korean paper manufacturers provides disadvantages in terms of protecting ideas, and it is important to secure large amounts of water, an important component in manufacturing Korean paper. Concerning the types of support, three companies wished to access financial support, and other companies wished to find more markets, obtain subsidies for technicians and initiatives, have a Korean paper museum, have local governments purchase fixed quantities of products, and the revitalization of the economy. However, one company expected that the establishment of the Korean Paper Theme Park will become a great help in terms of the public relations of Korean paper. Concerning future plans, one company was planning to reduce the scale of its business, one company was planning to expand, and 12 companies were planning to maintain their current scales. The reason for the company that so expressed, to reduce the scale of its business was that it had no initiatives, and that for the company wishing to expand its business was that the direct trade amount was increasing through the exhibition hall. 12 companies are planning to keep their current levels, but sought to expand the business when the demand level increases or the manufacturing conditions improve.

\section{CONCLUSIONS}

1. The average scale of paper mulberry cultivation has decreased by $60 \%$ from $1,469 \mathrm{~m}^{2}$ down to $875 \mathrm{~m}^{2}$, and the number of trees also decreased due to withering and negligence.

2. Excluding the one respondent, ten respondents in Goesan-gun responded that paper mulberry contributes up to $27 \%$ of the gross income of the household, while eight respondents in Suncheon answered that the average income from growing paper mulberry for each household was 330,000 won, only contributing $3 \%$ of the gross income of the household.

3. The one respondent in Goesan-gun hoped to expand the scale of cultivation. However, two respondents in Goheung-gun hoped to reduce the scale of cultivation due to high withering rates and the difficulties involved in bleaching bark. All eight respondents in Suncheon were planning to cultivate other types of plants.

4. The average working space of 14 Korean paper manufacturers was $505 \mathrm{~m}^{2}$. However, ten of them had less space than the average, and the average experi- ence level was 42 years, as many had been operating over generations.

5. Ten out of the 14 companies were operating all year round, and the annual average production of 11 companies was 190,000 sheets. The average yield was 700 million won for the three companies that had relatively large manufacturing spaces, whereas the average yield for the other 11 companies was 130 million won.

6. Concerning the method used to supply raw materials for the production of Korean paper, ten out of 14 companies were using imported paper mulberry and pulp, and were producing various products in small quantities, considering the decreased demand for traditional Korean paper and the development of various uses along with changes of consumer tastes.

7. Concerning the difficulties in producing Korean paper, respondents gave various responses, including a lack of technicians and initiatives. However, most companies intended to expand their businesses when the demand levels increased or when manufacturing conditions improved, while maintaining current scales for the time being.

The following implications were taken from this study:

1. The cultivation and production base for domestic paper mulberries is about to fall, due to the massive inflow of cheap foreign paper mulberry fiber and completed products already in stock. It is necessary to provide an environment where cultivators can produce paper mulberries easier, in order to secure a stable supply of high quality domestic raw materials and continue the traditional culture.

2 . It is necessary to move away from small-scale production using small fields and remaining land, toward large-scale production using forests and fields in order to hold a dominant position in terms of price competition with imported paper mulberry. This requires the leasing of national and publicly owned forests for planting paper mulberries and the financial support of the government. For the stable supply of raw materials, it is necessary to sign contracts with Korean paper manufacturers and to have the central or the local government support companies that manufacture Korean paper using 100\% Korean paper mulberry.

3. Most Korean paper manufacturers responded that they would maintain their current business scales, explaining that, despite the difficult business situation they faced, they maintained strong pride as families that have been involved in the industry for generations. They are, however, concerned that there are not many initiatives left to take. Therefore, it appeared that there must be support offered to foster trainees or initiatives to keep the life of the traditional Korean paper industry.

4. Some Korean paper manufacturers responded suggesting that the exhibition hall and the store became effective measures to expand the demand for Korean paper. Therefore, it is necessary to establish more 
exhibition halls and stores so as to develop various products and expand public relations when it comes to Korean paper, emphasizing the environmentally friendly nature of the raw materials used.

5. Currently, most products considered Korean paper are somewhat different from traditional Korean paper, with regards to the manufacturing method used, raw materials, the combination of materials, and so forth. It is therefore necessary to establish a clear concept of Korean paper, and differentiate its characteristics from normal Western paper, in order to keep the life of the traditional Korean paper industry, through the unsparing support of the government.

6. Lastly, it is necessary to remember that it would not be possible to manufacture high quality traditional
Korean paper without the stable supply of high quality Korean paper mulberries.

\section{REFERENCES}

Kim, J. S. 2005 Investigation on the Actual Status of Forestry Management (Paper Mulberry-Paper Bush Production Industry). Korea Forest Research Institute, Forest Science Information, 165: 20-21

Korea Agro-Fisheries Trade Corporation. 2007 Korea Agricultural Trade Information, Export and Import Statistics by Year

Korea Forest Service. 2001 Cultivation of Paper Mulberry and Traditional Korean Paper Industry

Korea Forest Service. 2006 Statistical Yearbook of Forestry

Korea Forest Research Institute. 2007 Internal Data, Titles and Addresses of Korean Paper Manufacturers 